TOMASZ GMEREK

Uniwersytet im. Adama Mickiewicza

w Poznaniu

\title{
SOCJALIZACYJNA FUNKCJA SZKOLNICTWA W AFRYCE POLUDNIOWEJ W OKRESIE APARTHEIDU (1948-1994)
}

\begin{abstract}
AвSTRACT. Gmerek Tomasz, Socjalizacyjna funkcja szkolnictwa w Afryce Południowej w okresie apartheidu (1948-1994) [Socialization Function of South African Education System During the Apartheid (19481994)]. Studia Edukacyjne nr 46, 2017, Poznań 2017, pp. 235-252. Adam Mickiewicz University Press. ISSN 1233-6688. DOI: 10.14746/SE.2017.46.15

The article is devoted to the discussion of socialization processes in the South African apartheid system of education (1948-1994). The socialization function of education is considered in-depth, with special attention paid to the racial inequality and discrimination in South African society. The article includes the consideration of school indoctrination and different aims of education and curricula in education subsystems for different racial groups in an Apartheid society.
\end{abstract}

Key words: education, socialization, indoctrination, South Africa, Apartheid, discrimination, curriculum, segregation, stratification

\section{Wprowadzenie}

Ewolucja systemu segregacji rasowej na terytorium Afryki Południowej następowała stopniowo, wraz z rozwojem państwowości, procesami industrializacji oraz instytucjonalizacji. Jednak dopiero wprowadzenie apartheidu jako systemu politycznego w 1948 roku usankcjonowało istnienie całej struktury zależności, w której kategoria rasy stała się wyznacznikiem funkcjonowania jednostek i grup społecznych we wszystkich sferach instytucjonalnych i pozainstytucjonalnych ${ }^{1}$. Trzeba zatem stwierdzić, że apartheid stanowił zinstytucjonalizowaną formę segregacji funkcjonującą na poziomie narodowym - system polityczny oparty na doktrynie odrębnego rozwoju poszczególnych kategorii rasowych $^{2}$.

${ }^{1}$ P.L. van den Berghe, Race and Racism. A Comparative Perspective, New York 1967, s. 96.

2 J. Balicki, Apartheid. Studium prawno-polityczne rasizmu w Afryce Południowej, Warszawa 1967, s. 174-190. 
Koncepcja systemu apartheidu stworzona została już w latach trzydziestych przez intelektualistów powiązanych z Partią Narodową. W 1948 roku, wraz z dojściem Partii Narodowej do władzy (po wygranych wyborach, w których jej reprezentanci głosili hasła segregacji rasowej i odrębnego rozwoju), rozpoczęto proces wprowadzania w praktykę społeczną jego zasad $^{3}$. Pod koniec lat czterdziestych XX wieku dostrzegalne były także zmiany lingwistyczne dotyczące samego słowa apartheid, które w języku afrikaans oznacza odrębność, separację. W tym czasie zastąpiło ono pojęcie segregacji [segregasie $]^{4}$.

R. Kapuściński stwierdza w tym kontekście, iż doktryna apartheidu

podniosła do godności prawa i zasady wiary najbardziej mroczny z ludzkich instynktów - wstręt rasowy. Mówi się że apartheid wymyślił Verwoerd. To nieprawda. Apartheid jest wytworem kolonialnym, jest rasistowską doktryną powołaną dla zabezpieczania zdobyczy kolonialnych. Apartheid towarzyszy kolonializmowi w ciągu całej wielowiekowej jego historii. W języku afrikaans "apartheid" oznacza "segregacja”. Ale jest to separacja w imię dominacji ${ }^{5}$.

Zwycięstwo Partii Narodowej w 1948 roku miało znaczący wpływ na kształt polityki oświatowej w kolejnych kilku dekadach. Zmiany, które rozpoczęły się wraz z dojściem do władzy afrykanerskich polityków zmierzały między innymi do rozszerzenia segregacji rasowej we wszystkich sferach funkcjonowania szkolnictwa. Wprowadzenie polityki apartheidu zmierzało do jak największej separacji pomiędzy jednostkami należącymi do jednej z czterech arbitralnie wyznaczonych kategorii rasowych (Białych, Azjatów, Koloredów oraz Czarnych). W 1954 roku Hendrik Verwoerd - Minister do Spraw Narodowości i późniejszy prezydent kraju - wyraził następujące słowa o edukacji dla niebiałych mieszkańców kraju:

Nie ma dla nich miejsca w społeczności Europejczyków poza sferą różnorodnych form pracy. Jakkolwiek, w ramach ich własnej społeczności wszystkie drzwi są otwarte. Z tego powodu bezużyteczne jest dla nich zdobywanie wykształcenia, które służy wejściu w społeczność Europejczyków, bowiem oni nie mogą w nią wejść. Do tego momentu byli oni przypisywani do systemu szkolnego, który odciągał ich od własnej społeczności i wprowadzał w błąd ukazując zielone pastwiska europejskiego społeczeństwa, na których oni nie powinni się paść.

Po dojściu do władzy, reprezentanci Partii Narodowej rozpoczęli działania mające na celu rekonstrukcję dotychczas funkcjonującego systemu szkol-

${ }^{3}$ H. Gilomee, L. Schlemmer, From Apartheid to Nation-Building, Cape Town 1989, s. 40-41.

${ }^{4}$ J. Balicki, Afrykanerzy, Afrykanie, Apartheid, Warszawa 1980, s. 39-40.

${ }^{5}$ R. Kapuściński, Faszyzm kartowaty, „Polityka”, 1963, 51-52 (355-356), s. 14.

${ }^{6}$ A. Wieder, White Teachers/White Schools: Oral Histories from the Struggle against Apartheid, Multicultural Education, 2003, 10, 4, s. 27. 
nictwa zgodnie z zasadami apartheidu. Dojście do władzy nacjonalistów afrykanerskich spowodowało skupienie pełni władzy w rękach jednej opcji politycznej ${ }^{7}$. Równocześnie, w jej ramach, funkcjonowały tajne organizacje, które w jeszcze większym stopniu służyły zamknięciu społecznemu w ramach dominującej (białej) kategorii społecznej. Jedną z najbardziej znaczących był Afrykański Związek Braterski [Afrikaner Broederbond - AB] ${ }^{8}$. Jak zauważa przy tym J. Balicki,

w okresie rządów Partii Nacjonalistycznej Broederbond stał się prawdziwą potęgą w państwie. Choć pozostał nadal organizacją tajną, nie było tajemnicą, że należą do niego wszyscy członkowie rządu, większość członków parlamentu, rektorzy większości uniwersytetów, większość sędziów, redaktorzy naczelni pism afrykanerskich, dyrektorzy afrykanerskich szkół średnich, setki duchownych i inni. Zajęcie wyższego stanowiska w administracji państwowej stało się praktycznie niemożliwe bez przynależności do Broederbondu, a przynajmniej bez aprobaty tej organizacji a aprobaty takiej nie uzyskiwały osoby wątpiące w słuszność polityki apartheidu9 .

Warto przy tym zauważyć, iż ta tajna organizacja miała kluczowy wpływ na szkolnictwo (które było postrzegane przez rząd Partii Narodowej za kluczową instytucję służącą odtwarzaniu i konserwowaniu istniejącego systemu). Zakłada się, iż spośród członków organizacji Broederbond znaczącą część stanowili ludzie powiązani ze szkolnictwem ${ }^{10}$.

W tym kontekście zarówno relacje pomiędzy edukacją, społeczeństwem i ekonomią (w tym rynkiem pracy), jak też rola szkolnictwa w procesach socjalizacji i formowania kapitału ludzkiego podporządkowane zostały idei przyświecającej twórcom doktryny apartheidu. Ich celem stało się ukształtowanie relacji rasowych $\mathrm{w}$ taki sposób, aby niebiała większość służyła białej mniejszości. W tym celu uchwalono różnorodne akty prawne, które dotyczyły sfery edukacji bezpośrednio (Ustawa o edukacji Bantu z 1953 roku [Bantu Education Act], Rozszerzenie ustawy o edukacji uniwersyteckiej z 1959 roku [Extension of University Education Act], Ustawa o edukacji Koloredów z 1963 roku [Coloured Persons Education Act], Ustawa o edukacji Hindusów z 1965 roku [Indian Education Act], Ustawa o edukacji narodowej z 1967 roku [National Education Act]) lub pośrednio (na przykład akty prawne uchwalone w 1950 roku, takie jak Ustawa o utworzeniu rejestru ludności [Population Registration Act], Ustawa o terenach grupowych [Group Areas Act], czy

${ }^{7}$ G. Bębnik, Ostatnia walka Afrykanerów, Biała Podlaska 2004, s. 152-154.

8 Por. tamże, tablice XIX-XXIV.

9 J. Balicki, Historia Burów. Geneza państwa apartheidu, Wrocław 1980, s. 221.

10 W.R. Johnson, Education: Keystone of Apartheid, Anthropology and Education Quarterly, 1982, 13, 3, s. 225. 
Ustawa o niemoralności [Immorality Act] ${ }^{11}$. Szkolnictwo zostało z premedytacją wykorzystane jako instrument dla realizacji tak sformułowanych politycznych celów twórców państwa apartheidu. Jak bowiem zauważa F. Troup, ,nigdzie jego dyskryminacyjne praktyki nie były bardziej widoczne i nigdzie nie zostały udokumentowane bardziej niż w sferze edukacji"12.

Celem artykułu jest analiza wybranych kontekstów działania szkolnictwa $\mathrm{w}$ procesach socjalizacji oraz indoktrynacji politycznej reprezentantów odmiennych kategorii rasowych w Afryce Południowej. Jego istotą jest zarówno omówienie przykładów wprowadzania założeń rasistowskiej ideologii w ramy treści kształcenia, jak charakterystyka dyskryminacyjnych działań podejmowanych w sferze segregowanego rasowo szkolnictwa. Ponadto, celem artykułu jest ukazanie powiązań pomiędzy celami edukacji i wychowania sformułowanymi z perspektywy kategorii rasowych, a sposobami działania struktury społeczno-ekonomicznej w Afryce Południowej.

\section{Zróżnicowanie rasowe, apartheid i procesy indoktrynacji ideologicznej w południowoafrykańskim szkolnictwie}

Już w latach dwudziestych XX wieku - a więc przed powstaniem sformalizowanego i uprawomocnionego politycznie systemu segregacji rasowej (apartheidu) - pojawiło się wyraźne zróżnicowanie w sferze treści kształcenia w szkolnictwie przeznaczonym dla odmiennych kategorii rasowych. Podziały w edukacji, wynikające początkowo z odmiennych sposobów finansowania szkolnictwa, stawały się coraz bardziej wyraźne ${ }^{13}$. Można zatem stwierdzić, że jeszcze przez wprowadzeniem polityki apartheidu podejmowano działania skutkujące tworzeniem podręczników oraz materiałów kształcenia zorientowanych na uwydatnianie i pogłębianie zróżnicowania rasowego. Treści miały w swoich założeniach konstytuować porządek oparty na nadrzędności białej rasy, a zadaniem edukacji stało się „inkorporowanie w tożsamość białych dzieci takiego społecznego oraz ideologicznego obrazu świata"14.

Po dojściu do władzy w 1948 roku Partii Narodowej rozpoczęto proces systematycznego wprowadzania segregacji rasowej we wszystkich sferach funkcjonowania szkolnictwa. Socjalizacyjna funkcja edukacji wykorzysta-

${ }_{11}$ M. Cross, L. Chisholm, The Roots of Segregated Schooling in Twentieth-Century South Africa, [w:] Pedagogy of Domination. Toward a Democratic Education in South Africa, red. M.O. Nkomo, Trenton 1990, s. 54.

12 F. Troup, Forbidden Pastures. Education under Apartheid, London 1976, s. 6.

13 J.D. Jansen, Curriculum as a Political Phenomenon: Historical Reflections on Black South African Education, The Journal of Negro Education, 1990, 59, 2, s. 199-200.

14 M. Cross, L. Chisholm, The Roots of Segregated Schooling in Twentieth-Century South Africa, [w:] Pedagogy of Domination, s. 52. 
na została do uprawomocniania systemu apartheidu. Proces wychowania w szkołach został zatem podporządkowany celom politycznym sformułowanym zgodnie z założeniami rasistowskiej doktryny segregacji. Rozpoczęto wprowadzanie programu politycznego dla białych szkół, których działanie opierało się na języku angielskim i afrikaans, na podstawie opublikowanego jeszcze przez wyborami Manifestu dla edukacji chrześcijańsko-narodowej [Manifesto for Christian National Education]. W dokumencie przeczytać można następujące założenia dla antycypowanego systemu:

Nasze afrykanerskie szkoły muszą nie tylko kształcić w ojczystym języku (...) muszą być one także miejscami, w których nasze dzieci będą przesiąkać i chłonąć chrześcijańsko-narodowe duchowe i kulturowe dziedzictwo narodu (...) Historia musi być nauczana zgodnie z planem nakreślonym przez Boga wobec ras ludzkich (...) Bóg chciał odrębnych narodów i ludzi. Edukacja tubylcza powinna być oparta na zasadach kurateli, nierówności i segregacji; jej celem powinno być wpajanie sposobów życia białego człowieka, w szczególności narodu Burów, który jest nadrzędnym powiernikiem ${ }^{15}$.

W szkołach dla Białych wprowadzono zatem program indoktrynacji ideologią chrześcijańsko-narodową. Ponadto, w kolejnych dekadach funkcjonowania państwa apartheidu, w sferze edukacji następowały procesy militaryzacji. Dla białej młodzieży organizowano specjalne paramilitarne organizacje; tworzono również obozy szkoleniowe dla chłopców. Oficerowie sił obrony regularnie odwiedzali szkoły wygłaszając wykłady. Istotą tych działań stało się wdrożenie do wojskowego drylu i przygotowanie do reagowania na potencjalne zagrożenia. Równocześnie, militaryzacja w sferze edukacji miała służyć zapoznawaniu z możliwościami uzyskiwania karier w sferze resortów siłowych. Ideologia bezpieczeństwa i militaryzmu obecna w szkolnictwie dla Białych odzwierciedlała sytuację polityczną i społeczną odnoszącą się do zróżnicowania rasowego i narastających konfliktów społecznych w RPA ${ }^{16}$.

Z kolei, w szkolnictwie przeznaczonym dla niebiałych kategorii rasowych cele kształcenia zostały zorientowane przede wszystkim na podporządkowanie nieuprzywilejowanych kategorii rasowych białej grupie dominującej. M. Nkomo wyróżnił pięć głównych celów, jakim podporządkowana była funkcja socjalizacyjna szkolnictwa w systemie apartheidu ${ }^{17}$.

Pierwszym celem była produkcja nisko wykwalifikowanej czarnej siły roboczej, która miała służyć potrzebom kapitalistycznej gospodarki kraju, generując zysk przy jak najniższych kosztach. Z tej perspektywy, cele działa-

${ }^{15}$ I. Robertson, P. Whitten, Race and Politics in South Africa, New Brunswick 1978, s. 106-107, podaję za: W.R. Johnson, Education: Keystone of Apartheid, s. 218.

${ }^{16}$ A. Sparks, The Mind of South Africa. The Story of the Rise and Fall of Apartheid, London 1990, s. 308-309.

17 M.O. Nkomo, Post-Apartheid Education: Preliminary Reflections, [w:] Pedagogy of Domination, s. 294-295. 
nia szkolnictwa dla Czarnych powiązane były z restrykcjami na rynku pracy i rezerwacją pewnych pozycji zawodowych wyłącznie dla Białych. Równocześnie, wraz z rozwojem ekonomicznym kraju oraz wzrostem protestów społecznych czarnych społeczności, działania Partii Narodowej zmierzały do zwiększenia zróżnicowania $\mathrm{w}$ ramach czarnej kategorii rasowej. W tym celu powstawały szkoły średnie oraz uczelnie wyższe dla czarnych (wiele z nich łączyło działania podejmowane przez prywatne podmioty, spółki, fundacje itp. z działaniami rządu). Pojawienie się czarnej klasy średniej miało stanowić bufor chroniący reżim apartheidu i dostarczać dowodów na faktyczne istnienie odrębnego rozwoju poszczególnych kategorii rasowych.

Drugi cel dotyczył socjalizacji czarnoskórych uczniów w sposób służący internalizacji porządku społecznego i prawnego apartheidu. Dotyczyło to przede wszystkim bezwzględnej akceptacji nadrzędności zachodniej, białej cywilizacji, a z drugiej strony - traktowania własnej pozycji jako "podrzędnej". Istotnym celem takiej socjalizacji było ugruntowanie przekonania, iż relacje dominacji i podporządkowania pomiędzy reprezentantami rasy białej i czarnej stanowią "zrządzenie boskie” i z tej perspektywy są nietykalne. Miało to swoje implikacje w procesie uprawomocniania przywódców władz prowincji - bantustanów, urzędników władz centralnych, a także w uległych relacjach wobec pracodawców.

Kolejny cel odnosił się do wzmacniania w sferze świadomości i tożsamości „białych” sposobów myślenia i postrzegania świata - w procesach kształcenia. Odnosiło się to między innymi do akceptacji powiązania pomiędzy białą rasą a kapitałem ekonomicznym $\mathrm{w}$ RPA ${ }^{18}$. Ponadto, celem stały się polityczne oraz ideologiczne działania służące uprawomocnianiu przekonania, iż przedstawiciele rasy białej stanowią naturalną dominantę w rasowo podzielonym południowoafrykańskim państwie ${ }^{19}$.

Czwarty cel zorientowany był na akceptację rasowej i etnicznej separacji. Kategoria „oddzielenia” uważana i promowana była jako naturalny stan rzeczy, który jest odzwierciedleniem potrzeb każdej poszczególnej kategorii rasowej. Równocześnie promowano przekonanie, że takie rozwiązania stanowią najbardziej optymalną odpowiedź na istniejące zróżnicowanie rasowe i etniczne kraju. Temu służyło utrzymywanie odrębnych szkół przeznaczonych dla reprezentantów odmiennych grup rasowych, a także segregacja mieszkaniowa w miastach oraz utrzymywanie bantustanów w obszarach wiejskich.

Piątym celem było utrzymywanie stanu niskiego rozwoju intelektualnego wśród członków nieuprzywilejowanych grup rasowych. Realizowany

18 Tamże.

19 J. Karlsson, Schooling Space: where South Africans learnt to position themselves within the hierarchy of apartheid society, Pedagogy, Culture and Society, 2004, 12, 3, s. 328. 
był za pośrednictwem odrębnych systemów szkolnictwa, których sposoby działania - oparte na ogromnych dysproporcjach - odzwierciedlały zróżnicowany stosunek białych władz do reprezentantów poszczególnych kategorii rasowych ${ }^{20}$. W.E. Morrow zwraca uwagę, że cele edukacji w Republice Południowej Afryki oparte były na zasadach kulturowego i moralnego relatywizmu. Implikowało to założenie, iż odmienne grupy rasowe mają odrębne i niekompatybilne kultury oraz style wychowania. W konsekwencji, cele edukacji muszą stanowić konstrukcję uwzględniającą te istotne różnice, a w konsekwencji - sankcjonować hierarchiczny porządek społeczny.

Temu właśnie założeniu służyły funkcjonujące de facto cztery odrębne systemy edukacyjne w Republice Południowej Afryki. Ich odrębne istnienie, działanie na odmiennych zasadach, w sferze inaczej sformułowanych celów i wartości, w zróżnicowany sposób finansowanych i zorganizowanych, sankcjonowało hierarchiczny porządek, w którym wychowywane były kolejne młode pokolenia. Jak to ujmuje W.E. Morrow,

te cztery odrębne systemy szkolnictwa służyły transmitowaniu głębokiego i podstępnego przekazu, opakowanego w naturalistyczną maskę, w której odgrywały organizującą rolę w konstruowaniu wspólnych znaczeń oraz ich rozumienia, służąc większości mieszkańców Południowej Afryki. Przekazy te były komplementarne dla czterech grup rasowych; one spajały i urzeczywistniały koncepcję grup rasowych, głęboko przenikały sposoby samopostrzegania jednostki, jej osobistych relacji oraz percepcji tego, gdzie ona przynależy $\mathrm{w}$ istniejącym hierarchicznym układzie, a także sankcjonowały jej rozumienie przebiegu głównych linii podziałów politycznych w społeczeństwie ${ }^{21}$.

Także treści kształcenia w jasny sposób eksponowały ideę nadrzędności białej rasy nad ludźmi posiadającymi inne pochodzenie rasowe (symbolizowane w najbardziej dobitny sposób przez swój kolor skóry) ${ }^{22}$. Programy kształcenia dla czarnych uczniów zorientowane były - jak już o tym pisano - do kształtowania poczucia ich podległej pozycji i sankcjonowania w umysłach uzasadnień dla niższego miejsca $w$ hierarchii społeczno-ekonomicznej ${ }^{23}$. Szkolnictwo zdominowane było przez - jak to ujmuje C. Harber - „silne, normatywne przekonanie o tym, iż Czarni powinni «znać swoje miejsce» w południowoafrykańskiej hierarchii władzy"24.

20 M.O. Nkomo, Post-Apartheid Education: Preliminary Reflections, [w:] Pedagogy of Domination, s. 295.

${ }^{21}$ W.E. Morrow, Aims of Education in South Africa, International Review of Education, 1990, 36, 2, s. 175.

${ }_{22}$ M.O. Bassey, Western Education and Political Domination in Africa: a study in critical and dialogical pedagogy, Westport 1999, s. 102-103.

${ }^{23}$ R.H. Davis, Producing the "Good African": South Carolina's Penn School as a Guide for African Education in South Africa, [w:] Independence without Freedom. The Political Economy of Colonial Education in Southern Africa, red. A.T. Mugomba, M. Nyaggah, Santa Barbara 1980, s. 83.

${ }^{24}$ C. Harber, Politics in African Education, London 1989, s. 186. 
Formowanie tego przekonania odnosiło się przy tym do trzech kluczowych obszarów oddziaływania pedagogicznego. Pierwszy odnosił się do sfery psychologicznej. Dotyczyło to przede wszystkim realizacji (za pośrednictwem wychowania) funkcji kontroli społecznej. Formowanie osobowości miało na celu podporządkowanie się obowiązującym zasadom, a w sylabusach uwydatniano potrzebę formowania u młodych ludzi takich cech, jak samodyscyplina, lojalność, uczciwość, odpowiedzialność, nastawienie religijne, właściwe maniery i schludny wygląd.

Drugi obszar dotyczył sfery edukacji szkolnej. Obejmował trzy główne wymiary. Pierwszym było posłuszeństwo względem obowiązujących zasad, zgodnie z przekonaniem, iż pod porządkowanie się regułom panującym w środowisku szkolnym ułatwi uczniom adaptację do istniejącej rzeczywistości społecznej. Drugi wymiar odnosił się do formowania szacunku wobec autorytetu władz szkolnych, nauczycieli, dyrektora oraz przedstawicieli instytucji oświatowych. Trzeci wymiar powiązany był z kontrolą uczęszczania do szkoły, co miało na celu ograniczenie zjawiska wagarowania.

Trzeci obszar oddziaływania pedagogicznego odnosił się do sfery doradztwa zawodowego. Także i ten obszar został silnie naznaczony ideologią apartheidu. Jego istotą stało się ukazywanie uczniom z czarnych społeczności tych sfer zawodowych, które w rasowo podzielonym społeczeństwie otwarte były dla czarnoskórych. Równocześnie, celem stało się podporządkowanie socjalizacji czarnych uczniów gospodarce opartej na nierównym i niesprawiedliwym podziale pracy ${ }^{25}$.

W niezwykle wyraźny sposób ideologia apartheidu obecna była w sferze treści kształcenia. Podręczniki szkolne tworzono na potrzeby państwa podzielonego wzdłuż kategorii rasowych. Dominowały w nich pewne stałe elementy, służące sankcjonowaniu w umysłach uczniów pożądanego (ze strony władzy politycznej) obrazu świata. Oto przykłady:

- historia prezentowana była z białej, eurocentrycznej perspektywy i pomijała historię Afryki sprzed kolonizacji;

- kolonizacja Afryki Południowej prezentowana była jako ekspansja osadników burskich w XIX wieku na niezamieszkanym wcześniej terytorium, co miałoby implikować tezę, iż ziemie te w naturalny sposób należą do białych;

- czarni traktowani byli jako problem i przeszkoda w realizacji celów zakładanych przez białych;

- rozwijano tezę, iż niebiałe społeczności nie wytworzyły odpowiedniego poziomu cywilizacyjnego, aby cieszyć się pełnymi prawami obywatelskimi oraz politycznymi. Implikowało to między innymi specyficzne postrzeganie człowieka czarnoskórego jako prymitywnego, nieinteligentnego, kłótliwego i konfliktowego ignoranta;

25 Tamże, s. 186-187. 
- kładziono nacisk na rozwój afrykanerskiego procesu narodotwórczego, jednak kiedy pojawiły się tendencje narodowościowe czarnych afrykańskich społeczności, zaczęto traktować je jako nierozważne, nielegalne, inspirowane z zewnątrz;

- rasowy podział pracy prezentowany był jako część porządku naturalnego, a bieda panująca w innych krajach afrykańskich prezentowana była jako konsekwencja rządów czarnej większości i nieobecności rządów białych ${ }^{26}$.

F.E. Auerbach - analizujący programy kształcenia oraz podręczniki do historii w szkołach średnich Transwalu (w pierwszych dekadach funkcjonowania systemu apartheidu) - zwraca uwagę na istotne przekłamania, nadinterpretacje oraz wyraźną tendencję indoktrynacji ideologicznej młodego pokolenia. Etnocentryczne stwierdzenia i rasistowskie poglądy przewijają się w opisach i charakterystyce faktów historycznych - zarówno w podręcznikach pisanych w języku afrikaans, jak i w książkach dla uczniów kształcących się w szkołach z innymi językami wykładowymi.

Historia prezentowana jest z białej perspektywy, w której uwydatniono kluczową rolę Afrykanerów w rozwoju państwa. Znaczenie kolonizacji Afryki Południowej białych osadników burskich traktowane jest równocześnie jako istotny wkład Europejczyków w rozszerzanie zachodniej cywilizacji. W niezwykle istotny sposób podkreśla się wagę religii chrześcijańskiej, jako podwaliny systemu społecznego i politycznego. W tym kontekście, kultury plemienne traktowane są jako barbarzyńskie, podległe i niższe, co implikuje konieczność ich nawracania i cywilizowania. Jak zauważa przy tym F.E. Auerbach,

białe dzieci uczące się historii oraz przedmiotów z nią powiązanych uzyskiwały wyolbrzymione przekonanie o znaczeniu historii Afryki Południowej w rozwoju cywilizacji, a w szczególności internalizowały błędny pogląd, iż Afrykanie są nadal na poziomie rozwoju plemiennego i nieodłącznie podrzędni wobec białych, a także ideę o rasowej istocie związku pomiędzy cywilizacją zachodnią, chrześcijaństwem i ludźmi białymi, z kaukaskiego pnia. Miało to dalszy wpływ na dzielenie ludzi ${ }^{27}$.

Podobne analizy dotyczące treści kształcenia zawarte w południowoafrykańskich podręcznikach przeprowadził J.M. Du Preez. Autor ten skupił się na badaniu podręczników szkolnych (z dziedziny historii, geografii oraz literatury w języku afrikaans) pod kątem występowania w ich narracjach i treściach kształcenia najważniejszych symboli dominacji białej rasy i roli narodu Afrykanerów. Wyróżnił on dwanaście kluczowych tematów, wokół których orientowała się narracja w badanych podręcznikach:

${ }^{26}$ C. Harber, Politics in African Education, s. 187.

27 F.E. Auerbach, The Power of Prejudice in South African Education. An enquiry into History textbooks and syllabuses in the Transvaal High Schools of South Africa, Cape Town 1965, s. 126. 
1. Zalegalizowane władze są niepodważalne.

2. Biali są nadrzędni; Czarni są podrzędni.

3. Afrykanerzy mają specjalne relacje z Bogiem.

4. Afryka Południowa pełnoprawnie należy do Afrykanerów.

5. Afryka Południowa jest krajem rolniczym; Afrykanerzy są narodem rolników [boervolk].

6. Afryka Południowa jest krajem dotykanym trudnościami (w sensie trudnych warunków klimatycznych, np. upałów, braku wody itp.).

7. Afryka Południowa i Afrykanerzy są odosobnieni (w sensie niezależności od innych, a także odwołania do historycznego wzorca pierwszych burskich osadników, będących rolnikami [boerwees], żyjących z dala od cywilizacji i zdanych tylko na siebie).

8. Afrykanerzy są zaradni i silni pod względem militarnym.

9. Afrykanerzy są zagrożeni (w odniesieniu do historycznych uwarunkowań życia Burów - trudności klimatycznych, konieczności nieustannych migracji, walk z tubylcami i osadnikami angielskimi, a także do współczesnych trudności, takich jak niepokoje społeczne, konflikty rasowe, czy trudności gospodarcze - także powiązane z kwestiami klimatycznymi).

10. Światowa opinia jest ważna dla Afryki Południowej.

11. Afryka Południowa jest liderem w Afryce.

12. Afrykanerzy mają w Afryce cel dany od Boga ${ }^{28}$.

Podobne wnioski wysuwają autorzy analizujący podręczniki do historii w szkołach Republiki Południowej Afryki - z perspektywy obecności w niej treści kształcenia dyskryminujących niebiałe społeczności, eksponujących nadrzędność rasy białej, a także sankcjonujących zasadność systemu politycznego opartego na zasadach apartheidu ${ }^{29}$.

E. Dean, P. Hartmann i M. Katzen sformułowali kilka głównych konkluzji w odniesieniu do tendencji obecnych $\mathrm{w}$ analizowanych przez siebie południowoafrykańskich podręcznikach do historii. Pierwsza z nich odnosi się do etnocentryzmu przenikającego podręczniki. Historia prezentowana jest przede wszystkim z białego, europocentrycznego punktu widzenia. Równocześnie, nieobecne są inne (na przykład tubylcze) sposoby widzenia rozwoju historycznego. Nie ma zatem $\mathrm{w}$ badanych podręcznikach informacji dotyczących prekolonialnej historii Afryki, Ameryki Łacińskiej, czy Azji. Orientują się one przede wszystkim na ukazywaniu rozwoju białych grup. Równocześnie, w badanych książkach tubylcze społeczności Afryki traktowane są jako problem i przeszkoda w realizacji celów zakładanych przez białych.

${ }^{28}$ J.M. Du Preez, Africana Africaner: master symbols in South African School Textbooks, Alberton 1983, s. 71-85.

29 E. Dean, P. Hartmann, M. Katzen, History in black and white: an analysis of South African school history textbooks, Paris 1983, s. 57. 
Druga istotna tendencja obecna $\mathrm{w}$ analizowanych podręcznikach związana jest z gloryfikacją nacjonalizmu. Nacjonalizm stanowi główną oś narracji, zarówno w analizach odnoszących się do historii Europy, jak i z perspektywy rozwoju narodu Afrykanerów. Zupełnie przeciwstawnie postrzegane są i charakteryzowane tendencje narodowościowe Afrykanów. Ruchy wyzwoleńcze afrykańskich społeczności traktowane są $\mathrm{w}$ analizowanych tekstach podręczników jako nielegalne, a także inspirowane z zewnątrz. Ewentualne tendencje narodowościowe odbierane są pozytywnie wyłącznie wówczas, kiedy odnoszą się do tubylczej lojalności i działań na rzecz wspierania polityki bantustanów.

Kolejną tendencją jest ukazywanie uwarunkowań przeszłości jako modelu dla kształtowania współczesnych uwarunkowań społecznych. Odnosi się to $w$ badanych podręcznikach do prezentowania segregacji rasowej, rasowego podziału pracy, czy systemu przepustek jako naturalnego stanu rzeczy - posiadającego odniesienia historyczne (datowane na wiek XVII i XVIII), co sankcjonuje ich istnienie w czasie.

Zbieżne z poprzednią tendencją są sposoby ukazywania zróżnicowania społecznego i ekonomicznego pomiędzy poszczególnymi kategoriami rasowymi. Rasowy porządek stratyfikacyjny i odpowiadający mu niesprawiedliwy podział pracy prezentowany był jako część porządku naturalnego. Równocześnie, problemy biedy czy bezrobocia obecne w innych krajach afrykańskich przedstawiane były jako konsekwencja rządów społeczności afrykańskich.

Kolejną tendencją obecną $w$ badanych przez cy towanych autorów podręcznikach do historii było tworzenie i uwiecznianie mitów. Jednym z najbardziej powszechnych stała się teza o ekspansji Burów na niezaludnionym terytorium Afryki Południowej. Implikowało to założenie, iż dziewiętnastowieczna wędrówka Burów w kierunku północnym (Wielki Trek), a także eksploracja tery toriów niezamieszkanych w naturalny sposób czyni z nich własność białych. Równocześnie podkreślana była w tym kontekście jedność i solidarność narodu Afrykanerów oraz ich konsekwencja i upór w dążeniu do stworzenia państwa.

Ważnym elementem obecnym - co podkreślają E. Dean, P. Hartmann i M. Katzen - w każdym podręczniku do historii jest dyskredytacja przeciwstawnych ideologii politycznych. We wszystkich badanych podręcznikach obecna jest narracja antykomunistyczna (podkreślane są wyłącznie zagrożenia i wypaczenia ideologii komunistycznej). Podobne tendencje dostrzegalne są wobec ideologii liberalnych. Zgodna z liberalnymi ideałami rasowa równość jest $\mathrm{w}$ ten sposób dyskredytowana. Także liberalne ideały Wielkiej Rewolucji Francuskiej - wolność, równość, braterstwo - są w tekstach bada- 
nych podręczników krytykowane i charakteryzowane jako nieprzystające do rzeczywistości Afryki Południowej.

Istotną tendencją obecną $\mathrm{w}$ tekstach badanych podręczników do historii było wspieranie poglądu dotyczącego niekompetencji Afrykanów. Odnosiło się to z jednej strony do wyrażanego implicite założenia, iż niebiali nie osiągnęli jeszcze wystarczającego poziomu rozwoju cywilizacyjnego, aby mogli cieszyć się pełnymi prawami politycznymi i obywatelskimi. Pogląd ten dotyczył przy tym interpretacji faktów historycznych, jak i aktualnej sytuacji w relacjach rasowych. Odnosił się on między innymi do ówczesnej sytuacji w czarnych rezerwatach (bantustanach), w których to biali podejmowali większość kluczowych decyzji - dotyczących stricte spraw tubylczych. Z drugiej strony, uwydatniano problemy ekonomiczne, społeczne i polityczne nowo powstałych państw Afryki, sugerując ich związek z nieudolnością i brakiem kompetencji afrykańskich rządów.

Ostatnią z wyróżnionych tendencji obecnych w południowoafrykańskich podręcznikach do historii było przesycenie ich treściami rasistowskimi, opartymi często na stereotypizacji. Odnosiło się to między innymi do charakterystyki czarnych społeczności jako niezdolnych do tworzenia trwałych struktur państwowych, ich braku kompetencji w sferze zarzadzania, czy myślenia perspektywicznego. Istotnym elementem $\mathrm{w}$ ramach tej tendencji było traktowanie i prezentowanie Afrykanina jako człowieka prymitywnego, skorego do konfliktów, który równocześnie jest antyintelektualnym ignorantem. Obecna w podręcznikach tendencja podkreśla równocześnie przepaści istniejące pomiędzy kategoriami ludzi czarnych i białych, sankcjonując znaczenie białej nadrzędności i czarnej podrzędności ${ }^{30}$.

Można zatem stwierdzić, że południowoafrykańskie szkolnictwo realizując swoją funkcję socjalizacyjną, nastawione było na wzmacnianie politycznych założeń apartheidu. Zadania takie postawione były od początku trwania tego systemu i kontynuowane aż do jego odrzucenia w 1994 roku. Kształtowanie tożsamości młodego pokolenia było zatem silnie uwikłane w dominującą ideologię państwową. Dotyczyło to szkół na poziomie podstawowym i średnim, a także edukacji uniwersyteckiej ${ }^{31}$. Równocześnie, procesy te miały swoje szerokie implikacje w sposobach myślenia i postrzegania świata wśród członków wszystkich kategorii rasowych zarówno w czasach apartheidu, jak i długo po jego formalnym zniesieniu ${ }^{32}$.

Procesy indoktrynacji politycznej obecne były również w szkolnictwie wyższym. Poza arbitralnymi podziałami w sferze segregacji rasowej uczelni

30 Tamże, s. 103-104.

31 G.D. Yonge, Ideological alchemy: the transmutation of South African didactics (and fundamental pedagogics) into 'apartheid education', Journal of Curriculum Studies, 2008, 40, 3, s. 410.

32 A.A. Abdi, Apartheid and Education in South Africa: Select Historical Analyses, The Western Journal of Black Studies, 2003, 27, 2, s. 95-96. 
dla poszczególnych kategorii (które najbardziej dobitnie charakteryzowały istotę działania systemu apartheidu w edukacji), w szkolnictwie wyższym działały również mechanizmy socjalizacji służące kształtowaniu tożsamości i postaw umożliwiających wprowadzenie jednostek w podzieloną rasowo strukturę społeczną.

Jak wspomniano, jednym z celów wprowadzonego w 1948 roku syste$\mathrm{mu}$ apartheidu stało się utworzenie odrębnych instytucji dla reprezentantów każdej kategorii rasowej - na wszystkich poziomach funkcjonowania szkolnictwa. Edukacja wyższa stała się jedną z najbardziej widocznych sfer dyskryminacji rasowej - w ramach funkcjonowania systemu apartheidu. Już w 1948 roku dr D.F. Malan, premier z ramienia Partii Narodowej stwierdził w Parlamencie:

W naszych instytucjach uniwersyteckich powstała w ostatnich latach sytuacja, której nie można tolerować, stan rzeczy powodujący wzrost napięć, stający się przyczyną nieprzyjemnych relacji pomiędzy Europejczykami a nie-Europejczykami (...) My nie chcemy odmawiać edukacji wyższej nie-Europejczykom i podejmiemy każdy możliwy krok aby dostarczyć zarówno tubylcom jak i Koloredom możliwości kształcenia uniwersyteckiego tak szybko jak będziemy mogli, lecz w ich własnej sferze; innymi słowy w odrębnych instytucjach ${ }^{33}$.

W tym celu utworzono w latach pięćdziesiątych oddzielne instytucje kształcenia wyższego dla Afrykanerów, Koloredów i Hindusów (na przykład: University of the North dla Afrykanów mówiących językami Soto, Venda i Tsonga, University of Zululand dla członków plemion Zulusów, University of Western Cape dla Koloredów, a także University of Durban-Westville dla Hindusów). Ponadto, najstarszą uczelnię dla Afrykanów - University of Fort Hare - utworzoną w 1916 roku przeznaczono dla Afrykanów mówiących w języku kosa. Tworzenie odrębnych uniwersytetów dla poszczególnych kategorii rasowych miało trzy główne cele. Po pierwsze, uprawomocnianie i potwierdzanie idei odrębnych grup rasowych i etnicznych promowanej przez rządy Partii Narodowej. Po drugie, dostarczanie personelu dla nowo tworzonych jednostek terytorialnych. Po trzecie, wzmacnianie i odtwarzanie podległej pozycji społecznej i ekonomicznej reprezentantów odrębnych kategorii rasowych ${ }^{34}$.

Zasady obowiązujące na czarnych uniwersytetach znacząco różniły się od panujących na uczelniach dla białych. Dawały dominującą pozycję władzom rektorskim wywodzącym się zwykle z Partii Narodowej. W tym celu wprowadzono specyficzne regulacje prawne, odnoszące się w sposób szczegółowy do zasad funkcjonowania czarnych studentów w kolegiach etnicznych, na przykład:

${ }_{33}$ A.L. Behr, Education in South Africa. Origins, Issues and Trends: 1652-1988, Pretoria 1988, s. 92.

34 R.O. Mabokela, 'We Cannot Find Qualified Blacks': faculty diversification programmes at South African universities, Comparative Education, 2000, 36, 1, s. 98. 
1) studenci nie mogą opuszczać bezpośredniego otoczenia kolegium bez pozwolenia kierownika hostelu lub odpowiedniego przedstawiciela Rektora;

2) każda organizacja studencka czy działalność, w którą jest zaangażowany student, musi być uprzednio zaaprobowana przez Rektora;

3) żadne zgromadzenia nie mogą odbywać się na terenie kolegium bez zgody Rektora. Legalne stowarzyszenia studenckie mogą odbywać spotkania zgodnie z zasadami określonego regulaminu;

4) żadne czasopisma, publikacje, czy broszury, za które odpowiedzialni są w całości lub częściowo studenci, nie mogą być rozprowadzane bez pozwolenia Rektora w konsultacji z Radą Uczelnianą oraz Senatem Uczelni;

5) nie mogą być udzielane żadne oświadczenia do prasy przez studentów, czy w ich imieniu, bez zgody Rektora;

6) po konsultacji z Radą Uczelnianą oraz Senatem Uczelni Rektor może zawiesić lub usunąć studenta, który w jego opinii narusza te zasady bądź zachowuje się niewłaściwie ${ }^{35}$.

Także w wypadku studentów zaklasyfikowanych do kategorii Koloredów opracowano szczegółowe regulacje dotyczące sposobów ich funkcjonowania na terenie uczelni. Część z nich odnosiła się do typowych obowiązków studenta, takich jak konieczność uiszczania czesnego, kwestie proceduralne powiązane z rekrutacją, zasady uczęszczania na zajęcia i wykłady, czy kwestie powiązane $z$ odpowiedzialnością za ewentualne zniszczenie mienia uczelni. Część zasad stanowiła jednak jawną ingerencję w prywatność jednostek, służąc kontroli wybranych aspektów ich życia - za pośrednictwem władz uczelni. Warto w tym miejscu wymienić kilka z nich:

1. Student nie może być członkiem żadnej organizacji poza czy w uniwersytecie, bez zgody Rady Uczelnianej, a żadne stowarzyszenie czy związek nie może powstać bez aprobaty Rady Uczelnianej.

2. Komisje, na istnienie których wyraziła zgodę rada mogą odbywać spotkania zgodnie $\mathrm{z}$ ich własnym regulaminem, jednak żadne spotkania nie mogą mieć miejsca w obrębie uczelni bez zgody Rektora.

3. Żadne czasopisma, publikacje czy broszury, za które odpowiedzialni są w całości lub częściowo studenci, a także żadne ogłoszenia czy afisze nie mogą być rozprowadzane czy rozwieszane bez pozwolenia Rektora

4. Nie mogą być udzielane żadne oświadczenia do prasy przez studentów, czy w ich imieniu, bez zgody Rektora.

5. Uczestnictwo $\mathrm{w}$ zajęciach sportowych $\mathrm{w}$ obrębie uczelni $\mathrm{w}$ niedziele jest zabronione ${ }^{36}$.

Władze uczelni były skłonne regulować nawet ubiór studentów. Na przykład, w roku akademickim 1968-1969 wprowadzono zasadę dotyczącą ubioru,

${ }^{35}$ M. Horrell, A Decade of Bantu Education, Johannesburg 1964, s. 148.

${ }_{36}$ M. Horrell, The Education of the Coloured Community in South Africa 1652-1970, Johannesburg 1970, s. 153. 
jaki powinni nosić studenci zarówno na wykładach, jak i poza uczelnią. Sugerowano strój schludny i stosowny. Elementem wymaganym i obowiązkowym dla mężczyzn były krawaty. Z kolei kobiety nie mogły nosić spodni, czy ubrań $\mathrm{z}$ dżinsu ${ }^{37}$.

Można zatem stwierdzić, iż organizacja życia studenckiego była ściśle podporządkowana kontroli władz uczelni, które z kolei reprezentowały władzę państwową. Funkcja kontrolna szkolnictwa wyższego rozciągnięta została również na te sfery życia osobistego jednostki, które powiązane były z przejawami jej indywidualizmu i niezależności. Wszelkie przejawy niezależnego myślenia, które mogłyby prowadzić do zmiany istniejącego porządku społecznego zostały poddawane kontroli już w ramach procesu rekrutacji. Pozwalało to władzom na dokonywanie selekcji nie tylko dotyczącej osiągnięć uczniów - kandydatów na przyszłych studentów, lecz także na ich dobór pod kątem przydatności do funkcjonowania w systemie apartheidu i jego potencjalnej reprodukcji ${ }^{38}$.

Weryfikacja poglądów, sposobów myślenia i nastawienia potencjalnych studentów odbywała się już uprzednio - w szkolnictwie średnim. W rzeczywistości, oznaczało to głęboką ingerencję w sposoby myślenia uczniów, zarówno $\mathrm{w}$ trakcie trwania edukacji podstawowej i średniej, jak też z perspektywy ich potencjalnego kształcenia na poziomie szkolnictwa wyższego. Procesy rekrutacji dopełniały tego procesu, stanowiąc wieloetapowe "sito" oddzielające niewygodne jednostki od uczestnictwa w kształceniu wyższym. Procesy te nasiliły się po protestach i bojkotach studenckich. Opisując praktyki weryfikacji studentów na wybrane czarne uniwersytety, M. Horrell zwraca uwagę, iż uczniowie chcący studiować lub być ponownie przyjęci na Uniwersytet Fort Hare, Uniwersytet of the North, czy Uniwersytet Zululand musieli corocznie ubiegać się o pozwolenie na studiowanie i uzyskiwać zaświadczenie o dobrym sprawowaniu (najczęściej z własnego miejsca zamieszkania) pochodzące od ministra ds. religii, komisarza ds. ludności Bantu [Bantu Affairs Commissioner] lub od dyrektora szkoły, do której wcześniej uczęszczali ${ }^{39}$.

Także socjalizacja uniwersytecka, a więc procesy kształcenia i wychowania prowadzone na uczelniach wyższych, podporządkowane były zasadom funkcjonowania apartheidu. Jak zauważa przy tym M.T. Chika Sehoole,

sposób w jaki był zorganizowany program kształcenia, rodzaje przedmiotów przeznaczonych dla poszczególnych grup rasowych, dobór osób które uczyły tych przedmiotów oraz tego jak one były nauczane, wszystko to służyło potwierdzaniu nadrzęd-

${ }^{37}$ Tamże, s. 154.

${ }^{38}$ M.O. Nkomo, Student Culture and Activism in Black South African Universities. The Roots of Resistance, Westport 1984, s. 39.

${ }_{39}$ M. Horrell, Bantu Education to 1968, Johannesburg 1968, s. 121. 
ności białej rasy i socjalizacji czarnoskórych do ról jakie przeznaczono im w ramach południowoafrykańskiego społeczeństwa ${ }^{40}$.

$\mathrm{W}$ historycznie czarnych uniwersytetach treści $\mathrm{w}$ ramach problematyki nauk społecznych, administracji, prawa, ekonomii, nauk ścisłych oraz teologii były znacznie ograniczone. Dobór zagadnień podporządkowany był wyłącznie funkcji przygotowania pracowników służby cywilnej na potrzeby tubylczych rezerwatów (bantustanów), stąd znacznie ograniczono ich zakres do niezbędnego minimum. Z kolei, uniwersytety dla białych oferowały znacznie poszerzone kursy w zakresie tych nauk, jak i studia nie oferowane w czarnych uczelniach, takie jak architektura, inżynieria, medycyna, czy stomatologia. Jako ciekawostkę warto podać, iż żaden uniwersytet przeznaczony dla Czarnych nie miał wydziału czy choćby kierunku inżynieryjnego powiązanego z górnictwem - w przeciwieństwie do uczelni białych, na których wydziały i kierunki takie były doskonale rozwinięte. W 1966 roku funkcjonowało 20 różnych wydziałów inżynieryjnych na pięciu spośród dziesięciu uniwersytetów dla Białych ${ }^{41}$.

Równocześnie, wyposażenie uczelni przeznaczonych dla reprezentantów poszczególnych kategorii rasowych znacznie się różniło. Często uczelnie dla czarnych studentów posiadały laboratoria i biblioteki, które były słabo wyposażone. Wiązało się to również z odmiennym finansowaniem uczelni dla odmiennych kategorii rasowych. W uniwersytetach dla Czarnych celem kształcenia relatywnie niewielkiej grupy studentów nie było kreowanie naukowców, czy osób dysponujących szeroką wiedzą o świecie, lecz w większym stopniu przygotowanie do odgrywania ról w administracji bantustanów, zajmowania stanowisk wymagających odpowiedniej wiedzy praktycznej, czy kształcenie nauczycieli szkół średnich. Z tej perspektywy widoczne dysproporcje w sposobach finansowania uczelni, ich wyposażenia, czy jakości kształcenia podkreślały przepaści obecne w relacjach rasowych ${ }^{42}$.

Trzeba równocześnie zaznaczyć, iż wiedza oferowana $\mathrm{w}$ ustawowo czarnych uniwersytetach była przekazywana i tworzona przez białych naukowców, którzy zwykle kształceni byli na afrykanerskich uniwersytetach. Powodowało to częste konflikty pomiędzy wykładowcami a studentami. Dotyczyły one wielu kwestii; warto w tym miejscu wskazać kilka z nich. Jedna $\mathrm{z}$ istotnych była powiązana $\mathrm{z}$ obcymi kulturowo materiałami kształcenia i często osadzonymi w logice apartheidu treściami (rasistowskimi, etnocentrycznymi, przesączonymi dyskryminacją). Inny problem powodujący kon-

${ }^{40}$ Ch.T. Sehoole, Democratizing Higher Education Policy. Constraints of Reform in Post-Apartheid South Africa, New York 2005, s. 21-22.

${ }^{41}$ Tamże, s. 22.

42 Tamże, s. 23. 
flikty dotyczył ewidentnych uprzedzeń wśród białych wykładowców, które obecne były w treściach wykładów. Istotna była również kwestia używanego języka - w szczególności na czarnych uczelniach, na których obowiązywał jako wykładowy język angielski. Dla wykładowców (pochodzących ze społeczności afrykanerskich i używających języka afrikaans), angielski stanowił język drugi. Często jego słaba znajomość wśród afrykanerskiego personelu akademickiego powodowała drwiny z wykładowców (stanowiąc płaszczyznę oporu wśród afrykańskich studentów wobec dominującej postawy białych wykładowców $)^{43}$.

\section{Zakończenie}

Podsumowując, można stwierdzić, iż edukacja w systemie apartheidu była wykorzystywana jako kluczowa instytucja służąca wprowadzaniu reprezentantów odmiennych kategorii rasowych w sposób myślenia zgodny z doktryną apartheidu. Instytucje edukacyjne służyły zatem indoktrynacji reprezentantów młodego pokolenia. Obowiązujące w południowoafrykańskim szkolnictwie modele socjalizacji wyposażały jednostki w cechy odpowiadające ich przynależności do odmiennych kategorii rasowych. Służyły w ten sposób kreowaniu odrębnych i rasowo zdeterminowanych tożsamości obywateli państwa - na potrzeby rasowo stratyfikowanego systemu społecznego, ekonomicznego i politycznego. Równocześnie, cele edukacji w Republice Południowej Afryki opierały się na założeniach, że reprezentanci poszczególnych kategorii rasowych mają odmienne kultury i style wychowania.

Socjalizacyjna funkcja południowoafrykańskiej edukacji podporządkowana została rasistowskiej ideologii, dyskryminującej reprezentantów niebiałych kategorii rasowych. Działanie szkolnictwa w RPA stanowi przy tym przykład instrumentalnego wykorzystywania instytucji edukacyjnych do realizacji celów politycznych, służących interesom grup dominujących w społeczeństwie.

\section{BIBLIOGRAFIA}

Abdi A.A., Apartheid and Education in South Africa: Select Historical Analyses, The Western Journal of Black Studies, 2003, 27, 2.

Auerbach F.E., The Power of Prejudice in South African Education. An enquiry into History textbooks and syllabuses in the Transvaal High Schools of South Africa, Cape Town 1965.

Balicki J., Apartheid. Studium prawno-polityczne rasizmu w Afryce Południowej, Warszawa 1967.

${ }^{43}$ Tamże, s. 21-22. 
Balicki J., Afrykanerzy, Afrykanie, Apartheid, Warszawa 1980.

Balicki J., Historia Burów. Geneza państwa apartheidu, Wrocław 1980.

Bassey M.O., Western Education and Political Domination in Africa: a study in critical and dialogical pedagogy, Westport 1999.

Behr A.L., Education in South Africa. Origins, Issues and Trends: 1652-1988, Pretoria 1988.

Bębnik G., Ostatnia walka Afrykanerów, Biała Podlaska 2004.

Cross M., Chisholm L., The Roots of Segregated Schooling in Twentieth-Century South Africa, [w:] Pedagogy of Domination. Toward a Democratic Education in South Africa, red. M.O. Nkomo, Trenton 1990.

Davis R.H., Producing the "Good African": South Carolina's Penn School as a Guide for African Education in South Africa, [w:] Independence without Freedom. The Political Economy of Colonial Education in Southern Africa, red. A.T. Mugomba, M. Nyaggah, Santa Barbara 1980.

Du Preez J.M., Africana Africaner: master symbols in South African School Textbooks, Alberton 1983.

Dean E., Hartmann P., Katzen M., History in black and white: an analysis of South African school history textbooks, Paris 1983.

Gilomee H., Schlemmer L., From Apartheid to Nation-Building, Cape Town 1989.

Harber C., Politics in African Education, London 1989.

Horrell M., A Decade of Bantu Education, Johannesburg 1964.

Horrell M., Bantu Education to 1968, Johannesburg 1968.

Horrell M., The Education of the Coloured Community in South Africa 1652-1970, Johannesburg 1970.

Jansen J.D., Curriculum as a Political Phenomenon: Historical Reflections on Black South African Education, The Journal of Negro Education, 1990, 59, 2.

Johnson W.R., Education: Keystone of Apartheid, Anthropology and Education Quarterly, $1982,13,3$.

Kapuściński R., Faszyzm karłowaty, „Polityka”, 1963, 51-52 (355-356).

Karlsson J., Schooling Space: where South Africans learnt to position themselves within the hierarchy of apartheid society, Pedagogy, Culture and Society, 2004, 12, 3.

Mabokela R.O., 'We Cannot Find Qualified Blacks': faculty diversification programmes at South African universities, Comparative Education, 2000, 36, 1.

Morrow W.E., Aims of Education in South Africa, International Review of Education, 1990, $36,2$.

Nkomo M.O., Student Culture and Activism in Black South African Universities. The Roots of Resistance, Westport 1984.

Nkomo M.O., Post-Apartheid Education: Preliminary Reflections, [w:] Pedagogy of Domination. Toward a Democratic Education in South Africa, red. M.O. Nkomo, Trenton 1990.

Robertson I., Whitten P., Race and Politics in South Africa, New Brunswick 1978.

Sehoole Ch.T., Democratizing Higher Education Policy. Constraints of Reform in Post-Apartheid South Africa, New York 2005.

Sparks A., The Mind of South Africa. The Story of the Rise and Fall of Apartheid, London 1990.

Troup F., Forbidden Pastures. Education under Apartheid, London 1976.

Van den Berghe P.L., Race and Racism. A Comparative Perspective, New York 1967.

Wieder A., White Teachers/White Schools: Oral Histories from the Struggle against Apartheid, Multicultural Education, 2003, 10, 4.

Yonge G.D., Ideological alchemy: the transmutation of South African didactics (and fundamental pedagogics) into 'apartheid education', Journal of Curriculum Studies, 2008, 40, 3. 